\title{
Tinjauan Terhadap Upaya STAIN Curup Dalam Meningkatkan Kemampuan Baca Al-Qur'an Mahasiswa
}

\author{
Hardivizon \\ Sekolah Tinggi Agama Islam Negeri (STAIN) Curup \\ hardi.vizon@gmail.com \\ Anrial \\ Sekolah Tinggi Agama Islam Negeri (STAIN) Curup \\ anrialma@gmail.com
}

\begin{abstract}
This study was designed to evaluate the efforts that was made by STAIN Curup in improving the ability of students to recite the Qur'an through Tahsin al-qirâ'ah courses. The goal was to determine how effective these efforts can improve the students to recite the Qur'an. This study was an evaluation which is a systematic scientific procedures that performed to measure the results of a program, whether or not the objectives planned is suitable. By collecting, analyzing and reviewing the implemention of the programs that was conducted objectively. Then formulating and defining the policy in advance to consider the positive values and benefits of the program. The informants of this study were the Head of STAIN Curup, Tahsin al-qira'ah Lecturers, and the second or thirdyear students. From the result of research, it was found that the efforts made by STAIN Curup to improve students's ability to recite al-Quran by requiring first-year students took tahsin al-qiraah courses was not very effective. It was shown from the low ability of the second and third students to recite al-Quran who have passed the course. $46.6 \%$ of students had low achievement. This happened because: (1) lack of time lecturing; (2) the lack of oversight and evaluation of the program by the Head of STAIN Curup, and (3) classification of students which were not based on the ability.
\end{abstract}

Keywords: Ability of reciting the Qur'an, STAIN Curup, Evaluation Research.

\begin{abstract}
Abstrak
Penelitian ini dirancang untuk melakukan evaluasi terhadap upaya yang dilakukan STAIN Curup dalam meningkatkan kemampuan baca al-Qur'an mahasiswa melalui mata kuliah Tahsin al-Qira'ah. Tujuannya adalah untuk mengetahui seberapa efektif upaya tersebut dapat meningkatkan kemampuan baca al-Qur'an mahasiswa. Penelitian ini merupakan penelitian evaluasi yaitu suatu prosedur ilmiah yang sistematis yang dilakukan untuk mengukur hasil suatu program, sesuai dengan tujuan yang direncanakan atau tidak. Caranya mengumpulkan, menganalisis dan mengkaji pelaksaaan program yang dilakukan secara objektif. Kemudian merumuskan dan menentukan kebijakan dengan terlebih dahulu mempertimbangkan nilai-nilai positif dan keuntungan suatu program. Informan penelitian ini adalah Pimpinan STAIN Curup, Dosen Tahsin al-Qira'ah, dan mahasiswa tahun kedua atau ketiga. Dari hasil penelitian,
\end{abstract}


diketahui bahwa upaya yang dilakukan STAIN Curup untuk meningkatkan kemampuan baca al-Quran mahasiswa dengan mewajibkan mahasiswa tahun pertama mengambil mata kuliah tahsin al-qiraah belum begitu efektif. Hal itu terlihat dari rendahnya kemampuan baca al-Quran mahasiswa tahun kedua atau ketiga yang yang telah dinyatakan lulus mata kuliah tersebut. 46,6\% mahasiswa memiliki kemampuan yang sangat rendah. Hal tersebut terjadi karena: (1) kurangnya waktu perkuliahan; (2) tidak adanya pengawasan dan evaluasi program oleh pimpinan STAIN Curup, dan (3) pengklasifikasian mahasiswa yang bukan berdasarkan kemampuan.

Kata Kunci: Kemampuan baca al-Qur'an, STAIN Curup, Penelitian Evaluasi.

\section{PENDAHULUAN}

Studi Islam yang dikonsepsikan oleh perguruan tinggi agama Islam di Indonesia menggambarkan bahwa al-Qur'an merupakan kajian inti dari berbagai disiplin ilmu yang mereka dalami, konsep jaring-jaring ilmu pengetahuan UIN Yogyakarta atau pohon ilmu UIN Malang adalah di antara contohnya. Nilai-nilai yang ada dalam al-Qur'an, digali secara mendalam melalui berbagai pendekatan, baik sains maupun pengetahuan modern, sehingga melahirkan ilmu pengetahuan yang khas.

Demikian pula halnya dengan Sekolah Tinggi Agama Islam Negeri (STAIN) Curup dengan konsep Petulai Keilmuan ${ }^{1}$, atau mata rantai ilmu yang diinspirasi dari konsepsi kultural yang tumbuh dan ditemukan pada etnis Rejang dimana perguruan tinggi tersebut eksis. Konsep ini menawarkan satu paradigma yang bersifat restoratif, namun masih dalam kerangka teo-antrokosmosentris-sistemik, yakni dalam memproduksi pengetahuan, manusia selalu berpijak pada tiga relasi; subjek dengan Tuhan (subject-SUBJECT relation); subjek dengan objek (subject-object relation); subjek dengan subjek (intersubjective relation). ${ }^{2}$

Paradigma keilmuan yang diangkat STAIN Curup tersebut menegaskan bahwa ilmu pengetahuan yang dibangun bersumberkan kepada pengetahuan-pengetahuan yang terdapat dalam al-Qur'an. Dengan

1 Tim Alih Status STAIN Curup, Naskah Akademik: Epistemologi dan Paradigma Keilmuan Istitut Agama Islam Negeri (IAIN) Curup.

2 Waryani Fajar Riyanto, Studi Islam Indonesia (1950-2014): Rekontruksi Sejarah Perkembangan Studi Islam Integratif di Program Pascasarjana Perguruan Tinggi Agama Islam (PTAI) dan AICIS, (Ponorogo: STAIN Ponorogo Press, 2014), hlm.582. 
kata lain, apapun disiplin ilmu yang didalami di STAIN Curup, sumber utamanya adalah al-Qur'an.

Atas dasar di atas, maka sangat urgen diperolehnya pamahaman Islam secara utuh dengan memahami al-Qur'an. Hal ini tampak dari argumentasi bahwa ide-ide yang terdapat di dalam kitab suci tersebut merupakan dasar normatif dan pondasi dari ajaran-ajaran Islam secara umum yang ditawarkan kepada manusia. Al-Qur'an memegang landasan moral bagi gagasan-gagasan dalam praktek semua disiplin ilmu, seperti ekonomi, politik, sosial dan lain sebagainya ${ }^{3}$

Dalam studi Islam, al-Qur'an termasuk sumber utama sebagai acuan dasar untuk pengembangan ilmu pengetahuan. Seperti yang telah disebutkan di atas bahwa al-Qur'an adalah sebagai sumber dari disiplin ilmu, makna yang terkandung di dalam kitab ini akan menjelaskan semua bentuk disiplin ilmu pengetahuan, walaupun secara bahasa semua ayatayatnya ditulis secara global dan membutuhkan penafsiran yang mendalam.

Al-Qur'an sebagai sumber utama ajaran Islam merupakan pedoman hidup bagi setiap muslim. Al-Qur'an juga mengintroduksikan ${ }^{4}$ dirinya sebagai pemberi petunjuk kepada jalan yang lurus. Petunjuk-petunjuknya bertujuan memberi kesejahteraan dan kebahagiaan bagi manusia secara umum, baik secara pribadi maupun kelompok. ${ }^{5}$

Oleh sebab itu setiap muslim dituntut untuk membaca, menguasai, menelaah dan mengamalkan semua kandungan yang tedapat di dalam alQur'an supaya tujuan hidupnya bisa tercapai dengan baik. Hal ini sangat penting karena untuk memahami ajaran Islam secara sempurna maka langkah pertama yang harus dilakukan adalah memahami kandungan isi

\footnotetext{
${ }^{3}$ Masdar Hilmy dan Akh Muzakki, Studi Islam, (Surabaya; IAIN Press, 2005), hlm.20.

${ }^{4}$ Mengintroduksi yaitu memperkenalkan dengan cara membuat nama masingmasing dengan tata cara yang lazin, (Departemen Pendidikan Nasional, Kamus Besar Bahasa Indonesia, ( Jakarta: Balai Pustaka, 2007), hlm. 440. Semisal yang berhubungan dengan tema di atas, yaitu terdapat di dalam surat al-Baqarah ayat 2 yaitu; "Kitab (alQur'an) ini tiada keraguan di dalamnya, petunjuk bagi orang yang bertakwa",

${ }^{5}$ Quraish Shihab, Membumikan Al-Qur'an, (Bandung: Mizan, 1996), hlm 172.
} 
al-Qur'an dan mengamalkannya dalam kehidupan sehari-hari secara sungguh sungguh dan konsisten. ${ }^{6}$

Dari hal-hal di atas, dapat dipahami bahwa kemampuan untuk membaca dan memahami isi kandungan al-Quran adalah sebuah keniscayaan bagi setiap mahasiswa STAIN Curup. Namun, fakta yang ada menunjukkan situasi yang memprihatinkan. Hampir separuh dari mahasiswa baru STAIN Curup memiliki kemampuan baca al-Quran yang buruk. Ini terlihat dari tes baca al-Qur'an bagi calon mahasiswa baru yang penulis ketahui sendiri pada setiap kali menjadi salah satu tim penguji.

Fakta ini tentu memprihatinkan. Di samping menggambarkan betapa buruknya pendidikan baca al-Qur'an bagi generasi muda, juga betapa beratnya beban yang akan dihadapi oleh para mahasiswa itu nanti. Bagaimana bisa mereka menggali pengetahuan dari al-Qur'an sebagai bentuk pengejawantahan konsep petulai keilmuan STAIN Curup, bila membacanya saja sudah tidak bisa?

STAIN Curup tidak menutup mata dengan kondisi ini. Oleh karenanya, berbagai upaya dilakukan untuk membantu mahasiswa mampu membaca al-Qur'an dengan baik dan benar. Secara legal formal, upaya yang dilakukan STAIN Curup adalah mewajibkan setiap mahasiswa lulus dalam mata kuliah Tahsin al-Qira'ah. Mata kuliah ini, dijalani selama satu semester pada tahun pertama mahasiswa masuk ke STAIN Curup. Meski berupa mata kuliah praktikum yang bernilai nol SKS, namun kelulusan mata kuliah ini menjadi syarat mutlak bagi mahasiswa untuk mengikuti kegiatan-kegiatan akademik selanjutnya, seperti Kuliah Kerja Pengabdian Masyarakat (KKPM), seminar proposal skripsi, dan munaqasyah.

Idealnya, mahasiswa yang sudah lulus mata kuliah tersebut, tentu sudah memiliki kemampuan baca al-Qur'an yang baik. Tetapi, fakta yang penulis temukan ketika mengajar mata kuliah Tafsir di berbagai program studi pada semester keempat atau lima, menunjukkan hal yang menyedihkan. Hampir 60\% dari mahasiswa semester lanjut tersebut tidak dapat membaca al-Qur'an dengan baik dan benar.

Hal inilah yang menjadi pertanyaan besar bagi penulis, seberapa efektifkah upaya STAIN Curup meningkatkan kemampuan baca al-

${ }^{6}$ Said Agil Husin Al Munawar, Al-Qur'an Membangun Tradisi Kesalehan Hakiki, (Jakarta: Ciputat Pers. 2002), hlm 3. 
Qur'an mahasiswanya melalui mata kuliah Tahsin al-Qira'ah tersebut? Upaya ini perlu untuk ditinjau dan dievaluasi.

Menurut William N Dunn evaluasi merupakan salah satu dari proses ataupun siklus kebijakan setelah perumusan masalah, implementasi, dan monitoring atau pengawasan terhadap implementasi kebijakan tersebut. Pada dasarnya, evaluasi kebijakan bertujuan untuk menilai apakah tujuan dari kebijakan yang dibuat dan dilaksanakan tersebut telah tercapai atau tidak. Evaluasi tidak hanya sekedar menghasilkan sebuah kesimpulan mengenai tercapai atau tidaknya sebuah kebijakan atau masalah telah terselesaikan, tetapi evaluasi juga berfungsi sebagai klarifikasi dan kritik terhadap nilai-nilai yang mendasari kebijakan, membantu dalam penyesuaian dan perumusan masalah pada proses kebijakan selanjutnya. Evaluasi merupakan salah satu dari prosedur dalam analisis kebijakan publik. $^{7}$

Sesuai dengan penjelasan di atas, permasalahan yang ingin dirumuskan melalui penelitian ini adalah: pertama, upaya apa saja yang dilakukan STAIN Curup dalam meningkakan kemampuan mahasiswa dalam membaca al-Qur'an?; kedua; seberapa efektif upaya tersebut dalam meningkatkan kemampuan baca al-Qur'an mahasiswa?; ketiga, kendala apa saja yang dihadapi dalam implementasi upaya tersebut?

Berangkat dari rumusan masalah di atas, maka tujuan penelitian ini adalah melakukan evaluasi terhadap upaya-upaya yang dilakukan STAIN Curup dalam meningkatkan kemampuan membaca al-Qur'an bagi mahasiswa, melalui: pertama, mengetahui landasan dan tujuan kebijakan ini; kedua, mengetahui bagaimana implementasi kebijakan tersebut; ketiga, menggali kendala apa saja yang dihadapi dalam proses pelaksanaannya; dan keempat, mengukur bagaimana hasil dari pelaksanaan upaya-upaya tersebut.

\section{Keadaan Mahasiswa STAIN Curup Dilihat dari Segi Kemampuan Baca Al-Qur'an.}

Tujuan penelitian ini adalah melakukan evaluasi terhadap upaya yang dilakukan STAIN Curup dalam meningkatkan kemampuan membaca alQuran bagi para mahasiswa. Sebelum melakukan evaluasi terhadap

\footnotetext{
${ }^{7}$ William N. Dunn, Pengantar Analisis Kebijakan Publik, (Yogyakarta: Gadjah Mada University Press, 2003), 608.
} 
kebijakan tersebut, penulis terlebih dahulu melakukan tes kemampuan baca al-Quran bagi mahasiswa. Tes dilakukan terhadap mahasiswa tahun kedua atau ketiga pada masing-masing program studi. Tujuan dari tes tersebut untuk mengetahui secara akurat, bagaimana kemampuan baca alQuran mereka. Tes dilakukan dengan cara mengambil sepuluh orang mahasiswa pada setiap program studi secara acak. Setiap mereka diminta untuk membaca ayat yang sama, yakni surat Maryam ayat 1-5.

Penilaian terdiri atas lima kategori yaitu, (a) tidak bisa, (b) bisa, tetapi masih mengeja, (c) bisa, tetapi tajwid masih kurang, (d) bisa, dan (e) sangat bisa. Berikut hasil dari tes tersebut:

Tabel 1. Hasil Tes Kemampuan Baca Alquran

\begin{tabular}{clcccccc}
\hline \multirow{2}{*}{ No } & \multirow{2}{*}{ Prodi } & \multicolumn{7}{c}{ Hasil Tes } & \multirow{2}{*}{ Jumlah } \\
\cline { 2 - 6 } & & $\mathrm{A}$ & $\mathrm{B}$ & $\mathrm{C}$ & $\mathrm{D}$ & $\mathrm{E}$ & \\
\hline 1 & PAI & & 8 & 2 & & & 10 \\
\hline 2 & PGMI & & 5 & 3 & 1 & 1 & 10 \\
\hline 3 & PBI & & 6 & 2 & 1 & 1 & 10 \\
\hline 4 & PBA & & & 5 & 2 & 3 & 10 \\
\hline 5 & BKI & & 5 & 3 & 2 & & 10 \\
\hline 6 & KPI & 2 & 6 & 2 & & & 10 \\
\hline 7 & IQT & & 3 & 3 & 2 & 2 & 10 \\
\hline 8 & PA & & 4 & 3 & 2 & 1 & 10 \\
\hline 9 & PS & & 5 & 3 & 1 & 1 & 10 \\
\hline Jumlah & 2 & 42 & 30 & 11 & 9 & \multirow{2}{*}{90} \\
\hline Presentase & $2,2 \%$ & $46,6 \%$ & $28,8 \%$ & $12,9 \%$ & 105 & \\
\hline
\end{tabular}

Dari hasil tes yang dilakukan, diketahui bahwa kemampuan baca alQuran mahasiswa STAIN Curup sebagai berikut: 1)tidak bisa membaca sebanyak $2,2 \%$; 2)membaca, tapi masih mengeja huruf sebanyak 46,6\%; 3)bisa membaca, tapi tajwid bermasalah sebanyak 28,8\%; 4) bisa membaca sebanyak $12,2 \%$; 5)sangat bisa membaca dengan baik sebanyak $10 \%$.

Dari sini tampak sekali kecenderungan mahasiswa dalam membaca al-Qur'an didominasi oleh mereka yang berada pada kategori "B" yaitu bisa, tapi masih mengeja. Kondisinya adalah, mereka masih terbata-bata dalam membaca al-Quran, kesulitan dalam merangkai huruf-huruf dalam ayat yang dibaca, dan bahkan beberapa di antaranya cukup lama untuk mengingat cara membaca huruf-huruf tersebut. 
Selain kategori kedua ini, beberapa di antaranya masih ada yang belum menguasai beberapa huruf hijaiyah sama sekali, sehingga mereka diposisikan kepada ketegori pertama, yang mana mereka tidak mampu untuk membaca ayat al-Qur'an.

Mahasiswa dengan kategori "C", yakni bisa membaca al-Qur'an tetapi bermasalah dalam hal tajwid, juga terlihat mendominasi. Kondisinya adalah mereka sudah bisa merangkai huruf-huruf al-Qur'an, namun tidak dapat membacanya dengan baik, sesuai kaidah tajwid, seperti mad, idgham dan waqf. Kejelasan makharij al-huruf juga menjadi masalah dalam kategori ini. Mereka tidak bisa membedakan dengan baik cara membaca masing-masing huruf, seperti $\dot{j}$ dan $j$, dan w, atau $\varsigma$ dan $\varepsilon$.

Mahasiswa yang dites tersebut merupakan mahasiswa yang sudah berada pada tahun kedua atau ketiga. Mereka merupakan mahasiwa yang telah mendapatkan perkuliahan tahsin al-qira'ah pada tahun pertama. Idealnya, kemampuan baca al-Quran mereka setelah perkuliahan tersebut mencapai level D atau E, yakni bisa membaca al-Quran dengan lancar.

Kenyataan ini menunjukkan kalau perkuliahan yang mereka peroleh belum memberi dampak yang signifikan untuk kemajuan kemampuan baca al-Quran mereka.

\section{Upaya yang Dilakukan Stain Curup untuk Meningkatkan Kemampuan Baca Al-Quran Mahasiswa}

Dalam mengatasi masalah kurang mampunya mahasiswa dalam membaca ayat al-Qur'an, STAIN Curup melakukan upaya untuk mengatasinya, yaitu membimbing dan membina mahasiswa melalui program yang dibentuk oleh STAIN disebut dengan tahsin al-Qiraah. Kegiatan ini diperuntukkan bagi mahasiswa tahun pertama dan dilakukan selama satu semester dengan jumlah pertemuan selama 16 kali tatap muka.

Menurut Sugiatno, Wakil Ketua I STAIN Curup, tujuan kegiatan tahsin al-Qiraah adalah untuk memberikan pendidikan dasar kepada mahasiswa agar mereka mampu untuk membaca ayat-ayat al-Qur'an. Mahasiswa dikelompokkan sesuai dengan kelompok kelas mereka dalam perkuliahan reguler. Setiap kelas, dibimbing oleh seorang dosen yang ditunjuk oleh Ketua Program Studi (Prodi). Dosen yang mengampu mata 
kuliah ini, diberi honor sesuai dengan ketentuan honor mata kuliah praktikum $^{8}$.

Mahasiswa yang lulus dari mata kuliah ini akan mendapatkan sertifikat yang menjadi prasyarat untuk mengambil mata kuliah Kuliah Kerja dan Pengabdian Masyarakat (KKPM) pada semester 6. Kemampuan baca al-Quran juga menjadi salah satu materi ujian pada sidang munaqasyah skripsi mahasiswa. Sebelum skripsi diujikan, mahasiswa bersangkutan diwajibkan membaca al-Quran terlebih dahulu di hadapan dewan penguji. Bila dianggap kurang baik, pimpinan sidang menyarankan kepada yang bersangkutan untuk lebih meningkatkan kemampuan baca al-Qurannya lagi. Secara khusus, kemampuan baca alQuran tersebut tidak terlalu berpengaruh terhadap kelulusan skripsi seorang mahasiswa, meskipun diujikan dalam sidang munaqasyah ${ }^{9}$.

Tidak ada metode khusus yang diwajibkan untuk dipakai oleh para dosen mata kuliah tahsin al-qiraah tersebut yang diterapkan oleh STAIN Curup. Sepenuhnya diserahkan kepada dosen yang bersangkutan. Namun, berdasarkan saran dari beberapa dosen, metode yang direkomendasikan oleh STAIN Curup kepada dosen pembimbing adalah metode an-nur ${ }^{10}$.

Metode an-nur memungkinkan seseorang belajar dari nol hingga bisa baca al-Qur'an beserta tajwid-nya hanya dalam waktu 2 jam. Metode ini merupakan metode belajar membaca al-Qur'an sistem cepat, walaupun sebelumya para peserta didik belum pernah mengenal huruf hijaiyah sama sekali, maka dalam tempo delapan kali pertemuan berikutnya mereka akan dapat membaca al-Qur'an dengan lancar berikut huruf hijaiyahnya. ${ }^{11}$

Dalam setiap pertemuan, peserta didik diberi tiga materi sekaligus, yaitu pengenalan huruf hijaiyah (setengah jam sampai satu jam), pengenalan tanda baca (setengah jam) dan sisanya pembacaan ayat-ayat pendek yang ada di dalam juz amma. Metode an-nur dalam pembelajarannya menggunaan analogi, yaitu hubungan logis atau

\section{5.}

${ }^{8}$ Sugiatno, Wakil Ketua 1 STAIN Curup, wawancara pada tanggal 09 Oktober

${ }^{9}$ Ibid.

${ }^{10}$ Lihat penelitian Ilda Hayati dan Busman Edyar dengan judul Efektivitas Pembelajaran Baca Qur'an Metode 'An-Nuur', Untuk Pemberantasan Buta Baca Qur'an Di STAIN Curup (Studi Kasus Mahasiswa Prodi PGMI Angkatan Tahun 2012/2013), tahun 2014

${ }^{11}$ Perpustakaan IAIN Walisongo, http://library.walisongo.ac.id/digilib/gdl.php 
hubungan yang di asumsikan antara dua hal, seperti analogi angka-angka Arab, analogi huruf-huruf hijaiyah dan analogi tajwid. ${ }^{12}$

\section{Tinjauan Terhadap Pelaksanaan Perkuliahan Tahsin al-Qiraah}

Dari data kemampuan baca al-Quran mahasiswa yang penulis sampaikan pada awal bab ini, terlihat bahwa perkuliahan tahsin al-qiraah di STAIN Curup belum memberikan hasil yang memuaskan. Untuk mengevaluasinya, penulis mencoba melihat dari beberapa sisi:

1. Waktu pelaksanaan

Durasi tatap muka dengan mahasiswa dalam kegiatan Tahsin alQiraah sebanyak 16 kali pertemuan selama satu semester. Sehingga perminggunya hanya satu kali tatap muka, setara dengan 90 menit. Waktu ini tentu terasa pendek, terutama bagi mahasiswa yang belajar membaca al-Qur'an memulainya dari nol.

Jumlah waktu yang singkat ini, akan sangat terasa pada prodiprodi dengan jumlah mahasiswa yang cukup banyak, seperti PAI, PBI, PS. Rata-rata, jumlah mahasiswa perlokalnya 30 orang. Tentu saja hal ini membuat perkuliahan menjadi tidak bisa berjalan secara maksimal.

Sri Widihayati sebagai salah seorang dosen pengampu mata kuliah ini mengungkapkan bahwa nilai mahasiswa masih di bawah standar dikarenakan minimnya waktu untuk memberikan pembelajaran kepada mereka. ${ }^{13}$

2. Evaluasi dan Pengawasan

Agar Program ini dapat berjalan dengan baik, maka diperlukan evaluasi dan pengawasan yang mendalam sehingga permasalahanpermasalahan yang mempengaruhi program ini dapat teratasi dengan baik. Dalam hal ini, selama program kegiatan tahsin al-Qiraah berjalan, pengawasan terhadap program ini belum dilakukan sepenuhnya, sebagaimana yang diungkapkan oleh Busra Febriyarni,

\footnotetext{
${ }^{12}$ Ibid.

${ }^{13}$ Sri Wihidayati, Dosen Tahsin al-Qira'ah STAIN Curup, wawancara pada tanggal, 28 Oktober, 2015
} 
salah seorang dosen pembimbing tahsin al-Qiraah, bahwa "selama mengajar belum ada pengawasan yang dilakukan oleh pimpinan". ${ }^{14}$

Hal yang sama juga diungkapkan oleh Sri Widihayati, "belum adanya kebijakan STAIN dalam mengevaluasi kegiatan ini"15. Bahkan, sejak beliau mulai mengampu mata kuliah ini dari tahun 2003, belum ada sekalipun kegiatan evaluasi yang dilakukan oleh Pimpinan STAIN Curup terhadap hasil perkuliahan maupun prosesnya. $^{16}$

Tidak adanya evaluasi dari pihak STAIN Curup memberi pengaruh besar terhadap bentuk pelaksanaan mata kuliah tahsin alqira'ah ini, termasuk terhadap metode yang digunakan oleh dosen pengampu. Masing-masing dosen menerapkan metode yang berbeda, meski sudah ada anjuran untuk menggunakan metode an-nur. Hal ini, seperti diungkapkan oleh Budi Birahmat, "saya tidak memakai metode an-nur dalam membimbing mahasiswa dan hanya menggunakan metode iqra', dan itulah yang rasanya paling tepat dibandingkan dengan metode an-nur". ${ }^{17}$

Walaupun metode an-nur telah menjadi anjuran dari STAIN Curup kepada dosen pembimbing tahsin, namun belum ada upaya khusus untuk melatihkan penerapannya kepada para dosen tersebut, sehingga, mereka tetap menggunakan metode, sesuai kecenderungan masing-masing. Oleh karenanya, metode ini belum begitu terasa dampaknya bagi kemajuan kemampuan baca al-Quran mahasiswa.

Begitu juga seperti yang diungkapkan oleh Sri Wihidayati bahwa materi yang pertama diperkenalkan adalah materi hukum tajwid terlebih dahulu setelah itu baru membaca al-Qur'an. ${ }^{18}$

Berhubungan dengan kebijakan STAIN terhadap program ini, menurut Yusefri sebagai salah seorang dosen pembimbing tahsin al-

${ }^{14}$ Busra Febriyarni, Dosen Tahsin al-Qira'ah STAIN Curup, wawancara pada tanggal, 28 Oktober, 2015

${ }^{15}$ Sri Wihidayati, op.cit.

${ }^{16}$ Ibid.

${ }^{17}$ Budi Birahmat, Dosen Tahsin al-Qira'ah STAIN Curup, wawancara pada tanggal, 27 Oktober, 2015

${ }^{18}$ Sri Wihidayati, Op.Cit. 
qiraah mengatakan bahwa "sampai sekarang tidak ada kebijakan resmi dari pimpinan". ${ }^{19}$

Dalam hal ini kebijakan yang dimaksud adalah berhubungan dengan masalah kurang mampunya mahasiswa membaca al-Qur'an dengan baik, walaupun program ini telah berjalan begitu lama namun setelah ada temuan kembali tentang kelemahan mahasiswa tersebut, sampai sekarang keputusan baru oleh pimpinan STAIN belum tampak sama sekali.

Mengenai koordinasi antara pihak STAIN dengan dosen tahsin, menurut beberapa dosen tahsin bahwa sampai sekarang koordinasi yang dilakukan oleh pihak STAIN termasuk mengenai perkembangan mata kuliah tahsin belum lagi dilakukan, sehingga situasi dalam kegiatan program ini tidak diketahui oleh pimpinan STAIN.

Begitu juga hubungan antara Unit Pengembangan Tilawatil Qur'an (UPTQ) dengan dosen pembimbing tahsin. Kurangnya koordinasi yang dilakukan menyebabkan lembaga ini tidak mengetahui hasil kemampuan mahasiswa, dan nilai mahasiswa yang dibuat oleh dosen pembimbing langsung diserahkan ke akademik STAIN Curup". ${ }^{20}$

3. Klasifikasi Kemampuan Mahasiswa

Melihat hasil tes yang dilakukan terhadap kemapuan baca ayat alQur'an mahasiswa seperti yang telah dijelaskan pada halaman sebelumnya, yang mana sesuai dengan ketegori penilaian yang telah diisi, tampak sekali kemampuan mahasiwa sangat berbeda. Hal ini disebabkan oleh jumlah mahasiswa yang sangat banyak tiap kelas, sehingga materi yang disampaikan tidak maksimal tersampaikan.

Sebagaimana yang telah diungkapkan oleh Sri Wihidayati bahwa "kemampuan mahasiswa bebeda sehingga sulit untuk disamakan materinya". Untuk itu, dibutuhkan pembagian kelompok mahasiswa sesuai dengan kemampuan mereka. Dengan demikian, mahasiswa dapat dilayani pembelajarannya, sesuai dengan kemampuannya dan tidak sia-sia.

${ }^{19}$ Yusefri, Dosen Tahsin al-Qira'ah STAIN Curup, wawancara pada tanggal , 28 Oktober 2015

${ }^{20}$ Sugiatno, Op.Cit. 
Dari pemaparan di atas, dapat penulis katakan bahwa pelaksanaan program tahsin al-qiraah yang bertujuan meningkatkan kemampuan baca al-Quran mahasiswa tidaklah berjalan dengan baik. Persoalan waktu, pengawasan dan klasifikasi mahasiswa berdasarkan kemampuan, adalah penyebab pokoknya.

\section{Tawaran Solusi}

Dari keterangan yang telah dijelaskan di atas, supaya program ini dapat berjalan dengan baik, maka diperlukan evaluasi yang mendalam sehingga permasalahan ini dapat diatasi dengan baik. Dalam hal ini, ada beberapa metode yang telah dilakukan oleh dosen tahsin al-Qiraah itu sendiri terhadap mahasiswa, yang nantinya dapat dijadikan bahan pertimbangan bagi pimpinan STAIN Curup.

Selain metode khusus yang digunakan oleh dosen Tahsin al-Qiraah dalam meningkatkan kemampuan mahasiswa STAIN Curup, begitu juga gagasan dari peneliti yang dapat dijadikan sebagai solusi, yang nantinya akan dikolaborasikan dengan cara-cara yang digunakan oleh beberapa dosen Tahsin al-Qiraah, sekiranya hal ini dapat digunakan untuk pengembangan progran ini selanjutnya.di antara solusi itu yaitu:

1. Kecukupan waktu pelaksanaan kegiatan tahsin al-Qur'an

Berhubungan dengan waktu pelaksanaan kegiatan program tahsin al-Qur'an, diharapkan bahwa waktu yang sebelumya hanya dilakukan selama 16 kali tatap muka selama satu semester atau satu kali pertemuan dalam seminggu dengan lama jam pertemuan hanya satu jam, maka diharapkan waktu pelaksanaan program ini diperpanjang, dan ini tergantung kepada keadaan kemampuan mahasiswa dalam membaca ayat al-Qur'an.

Jumlah jam pertemuan pada pelaksanaan program ini akan mempengaruhi kemampuan mahasiswa, yang mana apabila mahasiswa yang sama sekali tidak dapat membaca ayat al-Qur'an atau hanya mampu membaca namun masih terbata-bata, akan membutuhkan waktu yang sangat panjang supaya mereka mampu menguasai huruf-huruf yang ada dalam al-Qur'an.

Sebagaimana yang dikatakan oleh Busra Febriyarni dan Sri Wihidaningsih bahwa, "waktu satu kali dalam seminggu sangat sedikit sekali dan mata kuliah ini minimal pertemuannya tiga kali 
seminggu"21 sehingga untuk memfokuskan mata kuliah tahsin harus membutuhkan waktu yang panjang agar mahasiswa bisa membaca alQur'an secara merata.

Cara intensif yang diberlakukan kepada mahasiwa yang megikuti program tahsin dapat juga diberlakukan, apabila pelatihan membaca al-Qur'an dilakukan secara terus menerus selama satu atau dua semester, cara ini memungkinkan mahasiswa akan mampu menguasai huruf-huruf di dalam al-Qur'an.

Membimbing mahasiswa membaca al-Qur'an secara intensif, biasanya karena jumlah SKS mahasiswa pada semester awal dan kedua tidak begitu banyak, maka untuk memenuhinya akan ditambah dengan mata kuliah tahsin al-Qiraah. Waktu pelaksanaannya juga dilakukan pada pada jam ke empat tiap harinya dalam seminggu.

Hal ini di karenakan bahwa al-Qur'an adalah "ruh atau fungsi sebagai PTAI"22, maka tidak ada alasan upaya ini menjadi sebuah cara untuk memajukan mahasiswa.

Untuk menentukan kelompok mahasiswa sesuai dengan kemampuan mereka, ketika ada seleksi mahasiswa baru, pada tahap pengujian kemampuan baca al-Qur'an, maka nilai kemampuan mahasiswa harus berdasarkan kategori (bisa membaca atau tidak bisa membaca), dan dari hasil penilaian ini, bisa diambil patokan bahwa mereka harus mengikuti kegiatan tahsin.

Dalam hal ini, apabila ada di antara mahasiswa yang benar-benar sudah mampu membaca ayat al-Qur'an dengan baik, mereka tidak perlu mengikuti kegiatan tahsin lagi, program tahsin secara intensif hanya di berlakukan kepada mahasiswa yang tidak mampu baca alQur'an sengan baik.

2. Perlunya pelatihan dan workshop untuk semua dosen tahsin al-Qiraah

Untuk meningkatkan kinerja para dosen tahsin, sebelum mereka ditugaskan untuk membimbing mahasiswa, memberikan pembekalan kepada para pembimbing sangat diperlukan sekali, tujuannya adalah menyatukan persepsi mereka, yang nantinya dalam melaksanakan program tidak ada lagi kesalahan-kesalahan dalam membimbing mahasiswa.

\footnotetext{
${ }^{21}$ Busra Febriyarni dan Sri Wihidaningsih, Op.Cit.

${ }^{22}$ Ibid.
} 
Dalam kegiatan workshop ini, hal yang mendasar yang akan disampaikan adalah metode apa yang tepat untuk diberikan kepada mahasiswa yang mengikuti program tahsin, serta diskusi dengan para pembimbing tahsin yang selama ini sudah menjalankan program yang sudah di buat oleh STAIN.

Berhubungan dengan metode yang digunakan oleh dosen pembimbing tahsin berbeda-beda ${ }^{23}$, sehingga bukan metode an-nur yang dgunakan karena ada beberapa alasan seperti kemampuan mahasiswa yang berbeda-beda dalam membaca ayat al-Qur'an, bisa jadi metode yang digunakan selain metode an-nur dapat digunakan.

Dengan demikian ketika diadakan pelatihan dan workshop, para dosen tahsin diminta untuk memberi penjelasan tentang metode yang ia gunakan sebelumnya kepada mahasiswa, bagaimana cara menerapkannya, apakah nantinya dianggap praktis terhadap mahasiswa tertentu saja atau nanti, atau dapat digunakan kepada mahasiswa secara umum.

3. Adanya evaluasi dan kebijakan yang tepat dari pimpinan STAIN Curup

Tujuan dari evaluasi yaitu untuk melihat bagaimana sebuah program itu terlaksana oleh orang yang diberi tugas untuk melakukannya. Dalam hal ini, evaluasi ini dapat dilakukan kepada dosen pembimbing tahsih dan juga kepada mahasiswa yang mengikuti program ini, hal ini dikarenakan bahwa, evaluasi yang dilakukan kepada dosen pembimbing tahsin adalah berhubungan dengan metode yang mereka gunakan dalam membimbing mahasiswa supaya mampu membaca al-Qur'an.

Dalam melakukan evaluasi terdap dosen pembimbing tahsin, kegiatan ini dilakukan yaitu untuk mengumpulkan informasi bagaimana para pembimbing membina mahasiswa, menginterprestasikan informasi, dan membuat penilaian mengenai

23 Seperti halnya Budi Birahmat, ia menggunakan metode iqra' kepada mahasiswa bimbingannya, metode ini dianggap praktis karena susunan huruf hijaiyah yang terorganisi, dan ketika mahasiswa diminta untuk membacanya, akan dapat diketahui apakah yang di bacakan mahasiswa tersebut sudah benar ataukah belum, walaupun waktu proses bimbingan sangat panjang, namun dengan kondisi yang demikian akan memungkinkan para mahasiswa mampu menguasai huruf hijaiyah. 
tindakan apa yang harus dilakukan untuk meningkatkan kualitas pengajarannya.

Evaluasi terhadap dosen pembimbing tahsin merupakan proses analitis yang intrinsik dalam pengajaran yang baik, evaluasi terhadap dosen pembimbing tahsin merupakan suatu kesatuan mengajar yang baik, Pengajaran yang baik akan membantu mahasiswa untuk mencapai pembelajaran yang berkualitas baik.

Dalam hal ini tujuan dilakukan evaluasi terhadap dosen tahsin yaitu untuk: 1) meningkatkan kualitas pengajaran, 2) mengembangkan diri dosen; 3) meningkatkan kepuasan mahasiswa terhadap pengajaran tahsin al-Qiraah; 4) meningkatkan kepuasan dosen dengan metode yang ia gunakan serta hasil evaluasi yang dilakukan oleh pimpinan sebelumnya; 5) dapat mencapat tujuan program tahsin al-Qiraah; 6) secara umum adalah meningkatkan penilaian masyarakat terhadap hasil program ini, seperti mahasiswa yang melakukan KKPM ketika mereka membaca al-Qur'an, tidak ada lagi pertanyaan masyarakat mengapa lemahnya mahasiswa STAIN Curup dalam membaca ayat al-Qur'an.

Sedangkan evaluasi yang dilakukan kepada mahasiswa adalah untuk menilai kembali kemampuan mereka setelah mengikuti program tahsin, apakah diperlukan pembinaan terhadap mereka kembali bila kemampuan membaca ayat al-Qur'an mereka masih jauh dari yang diharapkan, sehinga nantinya diperlukan sebuah cara atau metode baru dalam membimbing mahasiswa.

Tujuan dilakukan evaluasi terhadap mahasiswa yang telah mengikuti program tahsin al-Qiraah adalah:

a. Tujuan Umum

1) Untuk menghimpun data tentang taraf kemajuan dan perkembangan mahasiswa yang mengikuti program tahsin alQiraah, dan setelah mereka mengikuti proses perkuliahan sebelumnya dalam jangka waktu tertentu, dan sampai dimana keberhasilan mereka dalam mengikuti program ini;

2) Untuk mengetahui efektifitas metode yang digunakan dalam program tahsin al-Qiraah yang digunakan dalam proses perkuliahan.

b. Tujuan khusus

1) Untuk merangsang semangat mahasiswa dalam mengikuti program tahsin al-Qiraah; 
2) Untuk mencari faktor keberhasilan dan kegagalan mahasiswa dalam mengikuti program tahsin al-Qiraah.

Dari tujuan di atas, evaluasi terhadap kemampuan mahasiswa dalam membaca al-Qur'an, dapat menentukan tindak lanjut dari hasil penilaian tersebut, seperti melakukan perbaikan dan menyempurnakan program yang telah dijalankan sebelumnya. Kegagalan mahasiswa dalam mengikuti program ini hendaknya tidak dipandang sebagai kekurangan pada diri mahasiswa itu sendiri, tetapi dapat disebabkan oleh program dan sistem pembelajaran yang diberikan kepada mereka, atau kesalahan strategi dalam melaksanakannya.

Mengenai kebijakan yang akan diupayakan STAIN kedepannya, sesuai apa yang katakan oleh Busra Febriyarni bahwa "pimpinan memberikan kebijakan yang ketat agar program ini dapat diperhatikan secara maksimal,"24

\section{Membuat LPTQ Tiap Jurusan}

Salah satu kelemahan pelaksanaan tahsin al-Quran yang penulis amati selama ini adalah penanganan yang kurang serius dari pihak jurusan atau prodi. Hal ini cukup wajar, karena fokus perhatian jurusan maupun prodi terpecah pada banyak aspek. Untuk itu, mendirikan Lembaga Pengembangan Tilawatil Quran (LPTQ) pada tingkat Jurusan, dipandang perlu. Agar, penanganan program ini dapat terlaksana dengan serius dan baik.

Rencana membuat LPTQ tiap jurusan ini sesungguhnya sudah ada dalam wacana pimpinan STAIN Curup. Hal ini, sebagaimana yang diungkapkan oleh Sugiatno, Wakil Ketua I STAIN Curup dalam wawancara dengan penulis. Menurutnya, pendirian lembaga ini tujuannya adalah "bukan saja untuk membaca al-Qur'an, namun untuk bagaimana cara membaca ayat al-Qur'an dengan baik". ${ }^{25}$ Dari tujuan rencana pendiriannya, maka hal-hal yang menjadi pokok pembahasan dari pihak STAIN Curup yaitu:

a. Setiap Jurusan harus ada LPTQ, yang mana nantinya lembaga ini yang menghandle kegiatan tahsin yang dilakukan oleh dosen pembimbing yang ditugaskan;

\footnotetext{
${ }^{24}$ Busra Febriyarni, Op.Cit.

${ }^{25}$ Sugiatno, Op.Cit.
} 
b. Merubah mata kuliah tahsin sesuai dengan tingkat kemampuan mahasiwa, dan dibuat kelompok-kelompok yang sesuai dengan kemampuan mahasiswa;

c. Dibuat penjadwalan terorganisir;

Pembentukan LPTQ tiap jurusan akan memudahkan pengkoordiniran terhadap kegiatan tahsin. Begitu juga sebagai gagasan salah satu pimpinan STAIN bahwa "pembentukan LPTQ per jurusan yang direncanakan tahun 2016 adalah untuk memudahkan hubungan antara dosen tahsin dengan lembaga ini". ${ }^{26}$

Walaupun nantinya lembaga LPTQ dibuat per jurusan, yang perlu diperhatikan adalah kesiapan lembaga ini dalam menghadapi permasaahan yang nantinya dapat dilihat dari dua segi, yaitu dari segi mahasiswa yang pada umumnya belum mampu membaca al-Qur'an dengan baik, serta dosen pembimbing tahsin yang akan membimbing para mahasiswa nantinya.

Penataan manajemen yang tepat pada program ini sangat diperlukan sekali, bukan hanya satu saja permasalahan yang harus diselesaikan yang menyangkut kemampuan mahasiswa dalam membaca ayat al-Qur'an namun banyak faktor seperti yang telah di jelaskan pada halaman sebelumnya.

5. Penambahan jam kuliah tahsin bagi mahasiswa yang belum lulus

Perbandingan kelulusan mahasiswa yang mengikuti program tahsin adalah dari 250 mahasiswa yang tidak lulus sekitar 50 orang. ${ }^{27}$ Walaupun demikian, jumlah yang lulus sekitar 200 orang tersebut belum bisa dikatakan lulus dari segi lancarnya membaca atau dari segi tajwid, seperti halnya ketika kami melakukan pengujian terhadap beberapa mahasiswa tiap-tiap prodi, yang mana kecenderungan mereka adalah membaca al-Qur'an masih terbata-bata, dan ada di antaranya yang masih lupa dengan huruf hijaiyah ketika membaca alQur'an.

Hal demikian disebabkan karena berkemungkinan mahasiswa yang sudah belajar tahsin, mereka tidak pernah mengulang bacaan alQur'an mereka di rumah sehingga ketika ada kesempatan mereka diminta untuk membacakan beberapa ayat yang mungkin

\footnotetext{
${ }^{26}$ Sugiatno, Op.Cit.

${ }^{27}$ Yusefri, Op.Cit
} 
berhubungan dengan mata kuliah, mereka sangat susah sekali membacanya. ${ }^{28}$ Sedangkan mengenai mahasiswa yang belum lulus, mereka diwajibkan mengulangi program ini pada semester berikutnya atau diasramakan serta dibimbing sesuai kurikulum yang ada di asrama.

6. Dibutuhkan pendanaan khusus untuk meningkatkan kegiatan tahsin al-Qiraah

Sesuai dengan yang dijelaskan oleh wakil Ketua 1 STAIN Curup bahwa "akan mengusahakan dana praktikum dikelola tersendiri", karena berkemungkinan kegiatan tahsin dilakukan membutuhkan waktu yang sangat panjang, maka penganggaran dana untuk kegiatan ini sangat dibutuhkan.

Dalam hal ini, perencanaan penganggaran sangat penting sekali karena berhubungan dengan salah satu fungsi peningkatan akademik mahasiswa dalam perguruan tinggi Islam. Untuk itu kegiatan tahsin al-Qira'ah yang diberlakukan khusus dan berkemungkinan ini dilakukan secara intensif, maka penganggaran berfungsi sebagai motivasi bagi para dosen tahsin al-Qiraah dalam membimbing mahasiswa dalam latihan membaca al-Qur'an.

Di sisi lain, anggaran digunakan sebagai pengendali kegiatan tahsin al-Qiraah, karena anggaran yang telah disetujui nantinya merupakan komitmen dari para pimpinan yang akan diberikan kepada para dosen tahsin al-Qiraah yang ikut serta dalam kegiatan tersebut, sehingga program ini dapat berjalan dengan baik.

\section{PENUTUP Simpulan}

Dari hasil penelitian tentang tinjauan tehadap kemampuan baca alQur'an mahasiswa STAIN Curup, dapat diambil kesimpulan sebagai berikut:

\footnotetext{
${ }^{28} \mathrm{Hal}$ ini sesuai dengan persepsi yang diungkapkan oleh Sri wihidaningsih tanggal 27 Oktober 2015 bahwa "mahasiswa tidak pernah mengulangi bacaan al-Qur'an atau jarang mengaji.

${ }^{29}$ Sugiatno, Op.Cit.
} 
1. Upaya yang dilakukan STAIN Curup dalam meningkatkan kemampuan baca al-Quran mahasiswa adalah dengan mewajibkan mahasiswa mengambil mata kuliah tahsin al-qiraah;

2. Upaya tersebut dirasa kurang efektif untuk meningkatkan kemampuan baca al-Quran mahasiswa. Dari hasil tes terhadap 90 orang mahasiswa yang diambil secara acak pada setiap prodi, 42 orang $(46,6 \%)$ memiliki kemampuan yang sangat rendah, yakni tidak mampu merangkai hurufhuruf al-Quran dengan baik, sehingga membacanya sangat terbata-bata (mengeja).

3. Kendala utama dalam pelaksanaan kegiatan tahsin al-qiraah tersebut adalah: a) Durasi pembelajaran yang sangat pendek. Dengan waktu tatap muka hanya 16 kali pertemuan dalam satu semester, mahasiswa hanya dapat belajar selama satu minggu satu kali dalam waktu 90 menit. Ditambah pula dengan jumlah mahasiswa yang banyak pada setiap kelasnya, sehingga waktu yang sedikit tersebut tidak mampu mengcover seluruh mahasiswa dengan baik; b) Pengawasan dan evaluasi yang sangat kurang dari Pimpinan STAIN Curup. Dengan ketiadaan ini, mengakibatkan dosen pengampu berjalan sendiri-sendiri dengan materi dan metode yang tidak standar; c) Klasifikasi mahasiswa yang tidak sesuai dengan kemampuannya. Mahasiswa dengan kemampuan yang beragam, digabung dalam satu kelas. Akibatnya, perkuliahan menjadi tidak efisien dan tidak mencapai target.

Dari penjelasan serta kesimpulan di atas, permasalahan membaca ayat al-Qur'an mahasiswa merupakan suatu hal yang sangat penting sekali dicarikan solusinya, karena membaca al-Qur'an adalah hal yang sangat vital sekali bagi perguruan tinggi Islam, yang mana setiap kegiatan perkuliahan pasti akan berhubungan dengan ayat-ayat alQur'an.

\section{Daftar Pustaka}

Bogdan, R. and Biklen,S., Qualitatif Research for Education, Boston, MA: Allyn and Bacon, 1992.

Cresswell, J. Research Design: Qualitative and Qualitative Approaches. Thausan Oaks, CA: Sage Publications, 1992.

Departemen Pendidikan Nasional. Kamus Besar Bahasa Indonesia. Jakarta: Balai Pustaka, 2007. 
Dunn, William N. Pengantar Analisis Kebijakan Publik. Yogyakarta: Gadjah Mada University Press, 2003.

Hilmy, Masdar dan Akh Muzakki. Studi Islam. Surabaya: IAIN Press, 2005.

Irawan, Prasetya. Logika dan Prosedur Penelitian. Jakarta : Sekolah Tinggi Ilmu Administrasi Negara, 1999.

Munawar, Said Agil Husin Al. Al-Qur'an Membangun Tradisi Kesalehan Hakiki. Jakarta: Ciputat Pers, 2002

Perpustakaan IAIN Walisongo,http://library.walisongo.ac.id/digilib/gdl. php

Riyanto, Waryani Fajar. Studi Islam Indonesia (1950-2014): Rekontruksi Sejarah Perkembangan Studi Islam Integratif di Program Pascasarjana Perguruan Tinggi Agama Islam (PTAI) dan AICIS, Ponorogo: STAIN Ponorogo Press, 2014.

Shihab, Quraish. Membumikan Al-Qur'an. Bandung : Mizan, 1996.

Sudjana, Nana dan R. Ibrahim. Metodologi Penelitian. Jakarta: Rineka Cipta, 1999.

Sugiyono. Memahami Penellitian Kualitatif. Bandung : Alfabeta, 2005.

Tim Alih Status STAIN Curup, Naskah Akademik: Epistemologi dan Paradigma Keilmuan Istitut Agama Islam Negeri (IAIN) Curup. 